\title{
Perkembangan Kultur Daun Aglaonema sp. dengan Perlakuan Kombinasi Zat Pengatur Tumbuh NAA dan 2,4-D dengan BAP \\ (The Leaf Culture Development of Aglaonema sp. Treated by Combination of NAA, 2,4-D and BAP as Growth Regulators)
}

\author{
Dwi Kusuma Wahyuni $i^{1)^{*}}$, Dedy Prasetyo ${ }^{1)}$, Sucipto Hariyanto ${ }^{1)}$ \\ ${ }^{1)}$ Departemen Biologi, Fakultas Sains dan Teknologi, Universitas Airlangga \\ ${ }^{\star}$ Email korespondensi: kusumaanwar@yahoo.com
}

Diterima 12 Agustus 2013, diterima untuk dipublikasikan 7 Januari 2014

\begin{abstract}
Abstrak
Tujuan dari penelitian ini adalah menentukan pengaruh kombinasi NAA dan 2,4-D dengan BAP terhadap perkembangan kultur daun dan konsentrasi yang sesuai untuk induksi kalus tiga kultivar Aglaonema sp. Kultivar-kultivar yang digunakan adalah Dynamic Ruby, Snow White, dan Siam Aurora. Eksplan daun dikulturkan pada medium MS padat dengan perlakuan kombinasi NAA dan 2,4-D dengan BAP. Hasil pengamatan minggu kedelapan menunjukkan ada pengaruh perlakuan zat pengatur tumbuh terhadap perubahan bentuk eksplan daun. Eksplan daun melengkung, bergelombang, membengkak, warna eksplan memucat dan membentuk kalus, tetapi hanya Aglaonema sp. cv. Dynamic Ruby yang mampu membentuk kalus. Kombinasi zat pengatur tumbuh 0,1 ppm 2,4-D and 1 ppm BAP adalah kombinasi yang sesuai untuk induksi kalus untuk Aglaonema sp. cv. Dynamic Ruby.

Kata Kunci: Aglaonema, NAA, 2,4-D, BAP, kalus
\end{abstract}

\begin{abstract}
The objective of this study were to determine the effect of combination of NAA and 2,4-D with BAP toward leaf culture development and to know the best concentration of growth regulator substance to induce callus on leaf explant of three Aglaonema cultivars. The cultivars were Dynamic Ruby, Snow White, and Siam Aurora. Leaf explants were cultured on solid MS medium with addition of various concentration combination of NAA and 2,4-D with BAP. Result of eight week observation gave significantly effect to changes shape leaf. Leaf blade was curved or rolled up, swelled, leaf color became pale strands, and formed callus, but the only cultivar which formed callus was Aglaonema sp. cv. Dynamic Ruby. The conclusion of this study was combination of growth regulator substance 0,1 ppm 2,4-D and 1 ppm BAP are the appropriate combination on callus inducing for Aglaonema sp. cv. Dynamic Ruby.

Keywords: Aglaonema, $N A A, 2,4-D, B A P$, callus

\section{PENDAHULUAN}

Aglaonema merupakan

tanaman hias daun, yaitu tanaman

hias dengan daya tarik utama terletak pada keindahan daunnya (Budiana 2007). Aglaonema termasuk tanaman yang pertumbuhannya lambat (Subono dan Andoko 2004), padahal permintaan pasar sangat besar.

Perbanyakan Aglaonema secara vegetatif melalui stek batang umum dilakukan, namun hasil tunas yang tumbuh hanya berkisar antara 1 hingga 3 tunas (Siar et al. 2002 dalam Qodriyah et al. 2007), sedangkan untuk budidaya ini diperlukan banyak bahan tanaman sehingga merusak tanaman induk, oleh karena itu saat ini mulai
\end{abstract}




\section{JURNAL BIOSLOGOS, FEBRUARI 2014, VOL. 4 NOMOR 1}

digunakan metode kultur jaringan untuk budidaya tanaman Agalonema (Hendaryono dan Wijayani 1994).

$$
\text { Usaha kultur Aglaonema }
$$

telah dilakukan dengan menggunakan eksplan nodus batang, seperti pada $A$. rotundum (Wannakrairoj 2000), Aglaonema cv. Cochin (Mariani et al. 2011), Aglaonema cv. Donna Carmen (Yulianto 2006), dan Aglaonema simplex (Laohavisuti dan Mitrnoi 2005). Penerapan metode kultur nodus batang pada Aglaonema akan mengambil bagian besar dari tanaman donor karena Aglaonema adalah tanaman dengan phylotaksis roset akar, sehingga masih diperlukan metode lain dalam budidaya Aglaonema.

Dengan kultur jaringan, tanaman Aglaonema sp. juga dapat diperoleh bibit dalam keadaan seragam melalui induksi embriogenesis somatik. Pada embriogenesis somatik tidak langsung, induksi kalus merupakan faktor penentu keberhasilan untuk perbanyakan tanaman (Ibrahim et al. 2010). Semakin banyak kalus yang dibentuk maka semakin tinggi peluang memperoleh bibit dalam jumlah yang banyak (George dan Sherrington 1992). Dengan teknik ini juga dapat menyebabkan variasi somaklonal yang menyediakan karakter tanaman yang diinginkan berupa varietas baru (Akbar et al. 2003). Oleh karena itu sangat diharapkan dapat diaplikasikan pada tanaman hias seperti Aglaonema.

Keberhasilan kultur jaringan untuk mengeksploitasi somaklonal variasi dipengaruhi genotipe tanaman (Tripathy dan Reddy 2002; Shirin et al. 2007), medium (Abadi dan Kaviani 2010), zat pengatur tumbuh (Hoesen et al. 2008; Jahan et al. 2009), dan fase perkembangan eksplan (Ibrahim et al. 2010; Reddy et al. 2011). Untuk induksi kalus embriogenik, genotipe tanaman dan komposisi medium adalah faktor penting penentu keberhasilan (Rachmawati et al. 2004).

Berdasarkan latar belakang tersebut studi ini bertujuan mengetahui pengaruh kombinasi NAA dan 2,4-D dengan BAP terhadap perkembangan kultur daun dan berapa konsentrasi yang sesuai untuk induksi kalus tiga cultivar Aglaonema sp. yaitu Dynamic Ruby, Snow White, dan Siam Aurora sebagai langkah awal embriogenesis somatik tidak langsung.

\section{METODE \\ Bahan penelitian}

Bahan yang digunakan sebagai eksplan pada penelitian ini adalah daun Aglaonema sp. cv. Dynamic Ruby, Aglaonema sp. cv. Snow White, dan Aglaonema sp. cv. Siam Aurora yang masih muda yang terdapat pada urutan kedua dan ketiga dari bagian pucuk, bahan kimia penyusun media Murashige dan Skoog (MS) (Murashige dan Skoog 1962), NAA, 2,4-D, BAP, akuades, chlorox $10-20 \%$, alkohol $70 \%$, spirtus, kertas payung, kertas saring, alumunium foil, karet gelang, kertas $\mathrm{pH}$, dan kertas label.

\section{Cara kerja}

Pada penelitian ini digunakan perlakuan kombinasi zat pengatur tumbuh NAA dan 2,4-D dengan BAP. Adapun perlakuan kombinasi perlakuan zat pengatur tumbuh yang digunakan adalah: A. untuk perlakuan NAA $0,1 \mathrm{mg} / \mathrm{l}$ dan BAP 1 $\mathrm{mg} / \mathrm{l}$, B. untuk perlakuan. NAA 0,2 $\mathrm{mg} / \mathrm{l}$ dan BAP $1 \mathrm{mg} / \mathrm{l}$, C. untuk perlakuan NAA $0,6 \mathrm{mg} / \mathrm{l}$ dan BAP $1,8 \mathrm{mg} / \mathrm{l}$, D. untuk perlakuan $\mathrm{N} \mathrm{AA}$ $0,8 \mathrm{mg} / \mathrm{l}$ dan BAP $1,6 \mathrm{mg} / \mathrm{l}$, E. untuk perlakuan NAA $0,1 \mathrm{mg} / \mathrm{l}$ dan BAP 1 $\mathrm{mg} / \mathrm{l}$ F. untuk perlakuan 2,4-D 0,1 $\mathrm{mg} / \mathrm{l}$ dan BAP $1 \mathrm{mg} / \mathrm{l}, \quad \mathbf{G}$ untuk perlakuan 2,4-D $0,2 \mathrm{mg} / \mathrm{l}$ dan BAP $1 \mathrm{mg} / \mathrm{l}, \mathbf{H}$. untuk perlakuan 2,4-D 0,6 $\mathrm{mg} / \mathrm{l}$ dan BAP 1,8mg/l, I untuk perlakuan 2,4-D $0,8 \mathrm{mg} / \mathrm{l}$ dan BAP 
$1,6 \mathrm{mg} / \mathrm{l}$ dan $\mathbf{J}$ untuk perlakuan 2,4D $1 \mathrm{mg} / \mathrm{l}$ dan BAP $1 \mathrm{mg} / \mathrm{l}$. Kombinasi zat pengatur tumbuh sesuai perlakuan ditambahkan medium MS padat, sukrosa 3\%, pH 5,6-5,8, agar $8 \%$. Media disterilkan dengan autoclave pada tekanan 1,2 atm $121^{\circ} \mathrm{C}$ selama 20 menit.

Eksplan disterilkan dengan cara menggunakan larutan Clorox $20 \%$ dan Clorox $10 \%$ sambil menggoyang-goyang selama 7 menit. Setelah itu membuang larutan Clorox dan membilasnya dengan aquades steril sebanyak 3 kali. Eksplan steril ditanam di media sesuai perlakuan. Kultur diinkubasi pada ruang inkubasi dengan suhu kamar dalam keadaan terang. Setiap minggunya diamati perkembangannya.

\section{HASIL DAN PEMBAHASAN Perkembangan Eksplan Daun Aglaonema sp.}

Eksplan daun Aglaonema sp. yang ditumbuhkan pada media MS dengan penambahan berbagai konsentrasi kombinasi zat pengatur tumbuh NAA dan 2,4-D, dengan BAP ternyata memberikan respon perkembangan yang bervariasi. Determinasi tahapan-tahapan perkembangan eksplan daun Aglaonema sp. dan ciri-ciri dari masing-masing tahapan didasarkan pada penelitian Rahmawati (2008) (Tabel 1).

Pada Aglaonema sp. cv. Siam Aurora perkembangan daun meliputi tahap 1, 2a, 2b, dan 3a, berarti perkembangan eksplan belum terbentuk kalus. Pada Aglaonema sp. cv. Snow White perkembangan daun meliputi tahap 1, 2a dan $3 a$, berarti perkembangan eksplan belum terbentuk kalus. Pada Aglaonema sp. cv. Dynamic Ruby perkembangan eksplan daun meliputi tahap 1, 2a, 2b, 2c, 3a, dan $3 \mathrm{~b}$, artinya perkembangan eksplan sudah mulai terbentuk kalus (Tabel 2 dan Gambar 1).

Tabel 1. Tahapan-tahapan perkembangan eksplan daun dari seluruh perlakuan dan ciri-ciri dari masing-masing tahapan (Rahmawati, 2008)

\begin{tabular}{|c|c|}
\hline $\begin{array}{l}\text { Tahapan } \\
\text { perkembangan }\end{array}$ & Ciri-ciri \\
\hline 0 & $\begin{array}{l}\text { Eksplan daun belum ada perkembangan, permukaan eksplan } \\
\text { daun rata, warna eksplan daun tetap,belum terbentuk kalus, tepi } \\
\text { eksplan daun berwarna coklat }\end{array}$ \\
\hline 1 & $\begin{array}{l}\text { Eksplan daun sedikit melengkung dengan sudut kemiringan (0- } \\
\left.30^{\circ}\right) \text {, permukaan eksplan daun rata, warna eksplan daun tetap, } \\
\text { belum terbentuk kalus, tepi eksplan daun berwarna coklat }\end{array}$ \\
\hline $2 a$ & $\begin{array}{l}\text { Eksplan daun melengkung }\left(30-90^{\circ}\right) \text {, warna eksplan daun tetap, } \\
\text { belum terbentuk kalus, permukaan eksplan daun rata. }\end{array}$ \\
\hline $2 b$ & $\begin{array}{l}\text { Eksplan daun melengkung }\left(30-90^{\circ}\right) \text {, warna eksplan daun berubah } \\
\text { menjadi lebih tua atau lebih muda, permukaaan eksplan daun } \\
\text { bergelombang (terjadi pembengkakan), belum terbentuk kalus. }\end{array}$ \\
\hline $2 c$ & $\begin{array}{l}\text { Eksplan daun melengkung }\left(30-90^{\circ}\right) \text {, warna eksplan daun berubah } \\
\text { menjadi lebih tua atau lebih muda, permukaaan eksplan daun } \\
\text { bergelombang (terjadi pembengkakan), terbentuk kalus. }\end{array}$ \\
\hline $3 a$ & $\begin{array}{l}\text { Eksplan daun melengkung } \geq 90^{\circ} \text { atau menggulung, warna eksplan } \\
\text { daun berubah menjadi lebih tua atau lebih muda, belum terbentuk } \\
\text { kalus. }\end{array}$ \\
\hline $3 b$ & $\begin{array}{l}\text { Eksplan daun melengkung } \geq 90^{\circ} \text { atau menggulung, warna eksplan } \\
\text { daun berubah menjadi lebih tua atau lebih muda, terbentuk kalus. }\end{array}$ \\
\hline 4 & $\begin{array}{l}\text { Eksplan daun melengkung } \geq 90^{\circ} \text { atau menggulung, warna daun } \\
\text { tetap, bagian tengah daun berwarna hijau/coklat/kuning }\end{array}$ \\
\hline
\end{tabular}




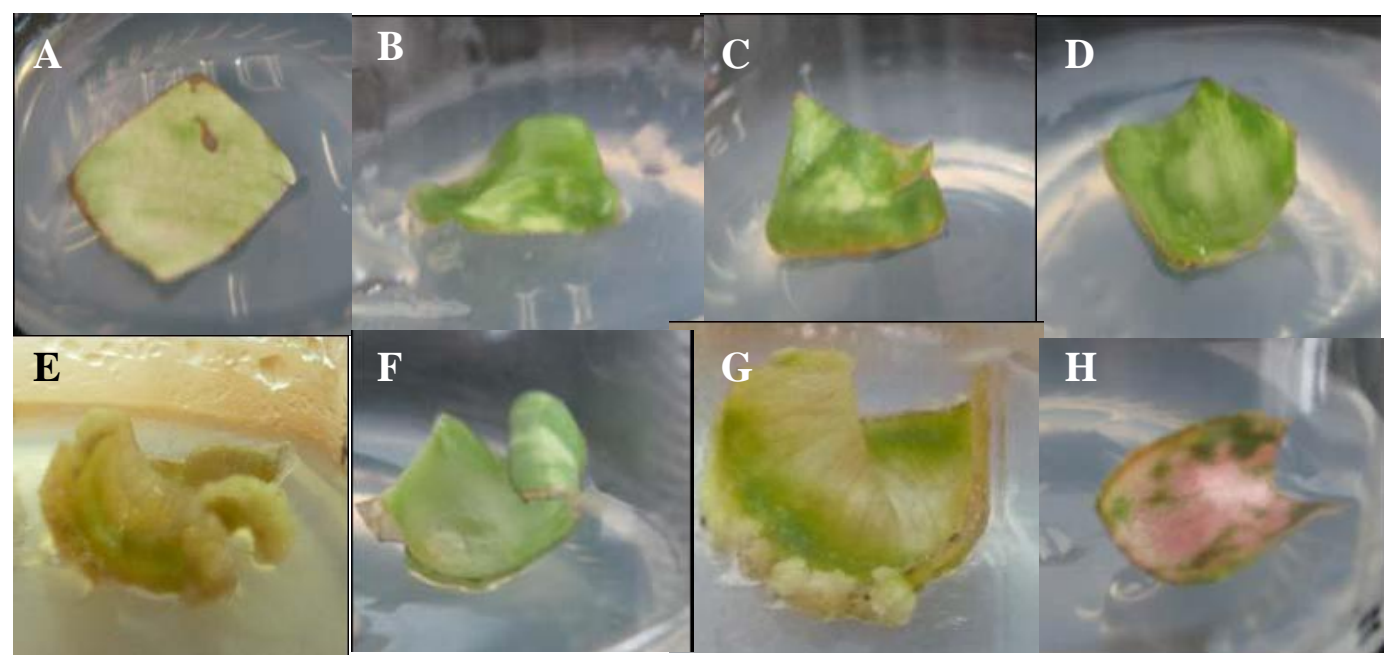

Gambar 1. Tahap perkembangan kultur daun Aglaonema sp. A. Tahap 1, B. Tahap 1, C. Tahap 2a, D. Tahap 2b, E. Tahap 2c, F. Tahap 3a, G. Tahap 3b, H. Tahap 4.

Induksi Kalus Aglaonema sp. cv. Dynamic Ruby

ini, pengamatan induksi kalus selama 8 minggu masa kultur belum menunjukkan hasil yang maksimal. Setelah minggu ke-28 masa kultur eksplan daun Aglaonema sp. cv. Dynamic Ruby memberikan respon yang baik untuk induksi kalus. Perlakuan A, B, C, F, $\mathrm{G}, \mathrm{H}$ dan $\mathrm{J}$ berhasil menginduksi kalus, sedangkan pada perlakuan $\mathrm{D}$, E dan I tidak berhasil menginduksi kalus. Kalus yang terbentuk berwarna putih kekuningan dengan tekstur kompak (Tabel 3, Gambar 2).

Tabel 2. Modus perkembangan eksplan daun Aglaonema sp. cv. Dynamic Ruby, Aglaonema sp. cv. Snow White, and Aglaonema sp. cv. Siam Aurora selama 8 minggu dengan perlakuan zat pengatur tumbuh 2,4-D, NAA dan BAP

\begin{tabular}{cccc}
\hline Perlakuan & \multicolumn{3}{c}{ Perkembangan eksplan daun selama 8 } \\
& $\begin{array}{c}\text { Aglaonema sp. cv. } \\
\text { Siam Aurora }\end{array}$ & $\begin{array}{c}\text { Aglaonema sp. cv. } \\
\text { Snow White }\end{array}$ & $\begin{array}{c}\text { Aglaonema sp. cv. } \\
\text { Dynamic Ruby }\end{array}$ \\
\hline A & $3 \mathrm{a}$ & $2 \mathrm{a}$ & $2 \mathrm{~b}$ \\
B & $2 \mathrm{a}$ & $2 \mathrm{a}$ & $2^{\mathrm{a}}$ \\
C & $2 \mathrm{~b}$ & $2 \mathrm{a}$ & $2^{\mathrm{a}}$ \\
D & $2 \mathrm{~b}$ & 1 & $2 \mathrm{~b}$ \\
E & $2 \mathrm{a}$ & 1 & $3^{\mathrm{a}}$ \\
F & $2 \mathrm{~b}$ & 1 & $2 \mathrm{c}$ \\
G & $2 \mathrm{a}$ & $2 \mathrm{a}$ & $2 \mathrm{~b}$ \\
H & $2 \mathrm{~b}$ & $3 \mathrm{a}$ & $2 \mathrm{~b}$ \\
I & 1 & 1 & 1 \\
J & 1 & 1 & $2 \mathrm{c}$ \\
\hline
\end{tabular}


Tabel 3. Persentase eksplan daun Aglaonema sp. cv. Dynamic Ruby yang membentuk kalus selama 28 minggu masa kultur $(n=3)$

\begin{tabular}{lcccccccccc}
\hline Perlakuan & $\mathrm{A}$ & $\mathrm{B}$ & $\mathrm{C}$ & $\mathrm{D}$ & $\mathrm{E}$ & $\mathrm{F}$ & $\mathrm{G}$ & $\mathrm{H}$ & $\mathrm{I}$ & $\mathrm{J}$ \\
\hline $\begin{array}{l}\text { Persentase eksplan } \\
\text { membentuk kalus } \\
(\%)\end{array}$ & 33,3 & 33,3 & 33,3 & 0 & 0 & 66,67 & 66,67 & 66,67 & 0 & 66,7 \\
& & & & & & & & & & \\
\hline
\end{tabular}
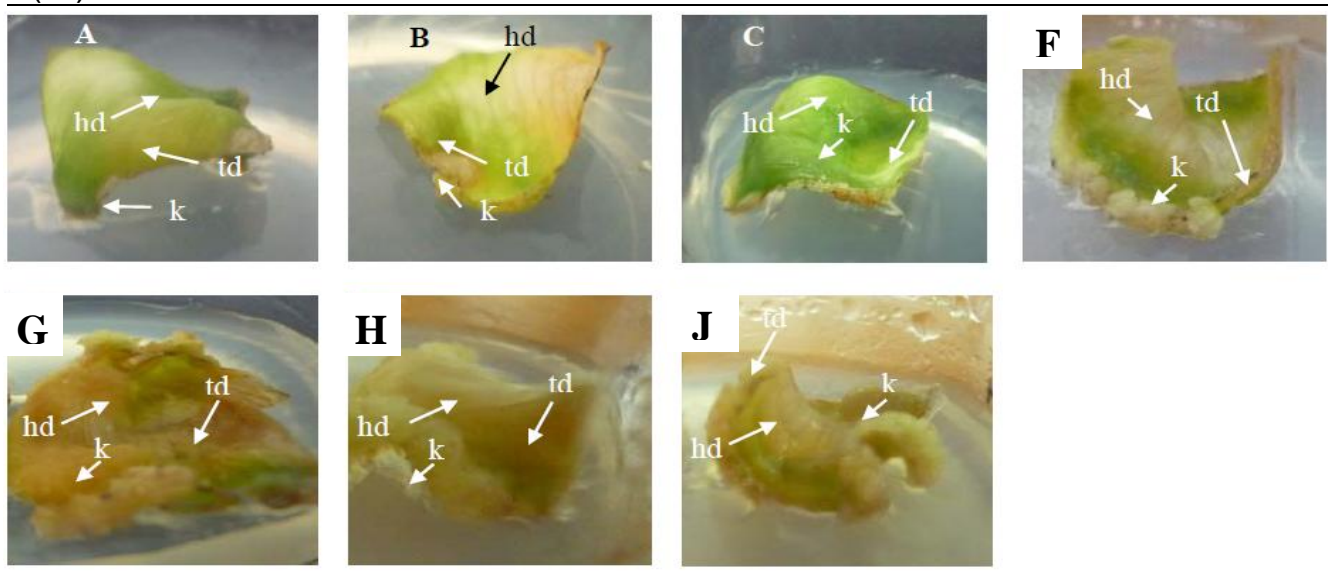

Gambar 2. Morfologi kalus eksplan daun Aglaonema sp. cv. Dynamic Ruby pada minggu ke-28. A untuk perlakuan NAA 0,1 mg/l dan BAP 1 $\mathrm{mg} / \mathrm{l}$, B untuk perlakuan NAA 0,2 $\mathrm{mg} / \mathrm{l}$ dan BAP $1 \mathrm{mg} / \mathrm{l}, \mathbf{C}$ untuk perlakuan NAA 0,6 mg/l dan BAP 1,8 mg/l, $\mathbf{F}$ untuk perlakuan 2,4-D $0,1 \mathrm{mg} / \mathrm{l}$ dan BAP $1 \mathrm{mg} / \mathrm{l}$, G untuk perlakuan 2,4-D 0,2 $\mathrm{mg} / \mathrm{l}$ dan BAP $1 \mathrm{mg} / \mathrm{l}, \mathbf{H}$ untuk perlakuan 2,4-D 0,6 $\mathrm{mg} / \mathrm{l}$ dan BAP 1,8mg/l, dan $\mathbf{J}$ untuk perlakuan 2,4-D $1 \mathrm{mg} / \mathrm{l}$ dan BAP $1 \mathrm{mg} / \mathrm{l}$ (Tahap 2c) $(\mathrm{hd}=$ helaian daun; $\mathrm{td}=$ tepi daun; $\mathrm{k}=$ kalus. Skala $=0,3 \mathrm{~cm}$ ).

\section{Pemberian}

perlakuan

kombinasi konsentrasi zat pengatur tumbuh pada varietas Aglaonema sp. memberikan respon berbedabeda. Respon yang berbeda tersebut dipengaruhi oleh beberapa faktor, baik internal maupun eksternal. Faktor internal adalah genotipe (Bai dan Qu 2000; Tripathy dan Reddy, 2002; Shirin et al. 2007), sedangkan faktor eksternal antara lain kombinasi zat pengatur tumbuh auksin dan sitokinin (Rashid et al. 2009; Abdelmageed et al. 2012).

Eksplan daun melengkung dan tulang daun membengkak disebabkan adanya pengaruh auksin dan tekanan turgor. Adanya auksin menyebabkan dinding sel mengendur dan merenggang. Pengenduran dinding sel ini terjadi karena adanya sekresi asam dengan mengaktifkan suatu enzim pada $\mathrm{pH}$ tertentu. Merenggangnya sel akan menyebabkan pemanjangan sel. Tekanan turgor terjadi apabila sel menyerap molekul air sebagai respon akan meningkatnya konsentrasi zat terlarut yang terdapat dalam vakuola, sehingga akan menyokong perluasan sel yang terjadi (Taiz dan Zieger 1998).

Pada penelitian ini pada minggu kedelapan kalus terbentuk pada eksplan Aglaonema sp. cv. Dynamic Ruby dengan perlakuan $\mathrm{F}$ dan J. Pembentukkan kalus disebabkan karena respons eksplan terhadap pelukaan (George dan Sherington 1992) untuk menutup luka (Dodds dan Robberts 1982). Kalus mulai terbentuk dari bekas irisan eksplan yang mana sel-selnya berhenti bermitosis dan mulai membentuk kalus seperti pada Solanum nigrum L. (Shidar dan Naidu 2011), Sonchus arvensi L. (Wahyuni et al. 2010), Trichosanthes dioica Roxb. (Komal 2011), dan 
Anthurium digitatum (Reddy et al. 2011).

Aglaonema sp. cv. Dynamic ruby mampu membentuk kalus pada minggu ke-8 masa kultur. Lama waktu yang dibutuhkan untuk induksi kalus cukup lama dibandingkan dengan induksi kalus pada tanaman lain. Kalus mulai muncul minggu ke2 masa kultur pada tanaman Sonchus arvensis, L. (Wahyuni et al. 2010), minggu ke-3 masa kultur pada Ananas comosus L. (Merr.), Cucumis melo L. (Melara et al. 2009), minggu ke 2-4 masa kultur pada Artemisia annua L. (Ganesan 2011), minggu ke 7-8 pada Anthurium digitatum dengan eksplan daun tua (Reddy et al. 2011), namun lama waktu ini relatif cepat dibandingkan dengan Aglaonema $s p$ cv. Lipstik yang membutuhkan waktu 14 minggu (Sukmadewi et al. 2012).

Kalus yang tumbuh pada eksplan daun Aglaonema sp. cv. Dynamic Ruby berwarna kuning dan memiliki tekstur yang kompak. Tekstur kalus kompak merupakan tekstur kalus yang padat dan tidak mudah lepas atau hancur. Kalus kompak berpotensi tumbuh atau berkembang menjadi organ (organogenesis), misalnya terbentuk akar atau tunas.

Dari penelitian ini dapat disimpulkan bahwa perlakuan kombinasi zat pengatur tumbuh NAA dan 2,4-D dengan BAP menyebabkan perkembangan eksplan daun Aglaonema sp. cv. Dynamic Ruby, Aglaonema sp. cv. Snow White, dan Aglaonema sp. cv. Siam Aurora menjadi melengkung, memanjang, dan menebal. Kombinasi perlakuan 2,4-D 0,1 mg/l dengan BAP $1 \mathrm{mg} / \mathrm{l}$ merupakan konsentrasi terbaik untuk induksi kalus pada Aglaonema sp. cv. Dynamic Ruby. Induksi kalus pada penelitian ini belum berhasil maksimal. Untuk meningkatkannya masih perlu dilakukan penelitian lagi dengan menggunakan zat pengatur tumbuh dan konsentrasi yang lebih bervariasi.

\section{UCAPAN TERIMA KASIH}

Penulis mengucapkan terima kasih kepada Bapak Mursyid yang telah menyediakan eksplan dan mendanai penelitian ini.

\section{DAFTAR PUSTAKA}

Abadi HD, Kaviani B (2010) In vitro proliferation of important medicinal plant Aloe:A method for rapid production. Australian Journal of Crop Science 4: 216-222

Abdelmageed AHA, Faridah QZ, Shuhada NK, Julia AA (2012) Callus induction and plant regeneration of Michelia champaca L. (Magnoliaceae): A multipurpose tree. Journal of Medicinal Plants Research 6: 3336-3344

Akbar AM, Karmakar KB, and Roy KS (2003) Callus induction and high-frequency plant regeneration of pineapple (Ananas comusus (L.) Merr.). Plant Tissue Culture 13:109116

Bai Y, Qu R (2000) An evaluation of callus induction and plant regeneration in twenty-five turf-ype tall fescue (Festuca arundinacea Schreb.) cultivars. Grass and Forage Science 55:326-330

Budiana NS (2007) Agar Aglaonema tampil memikat, Seri Agrohobi. Penebar Swadaya. Jakarta

Dodds JH, Robert LW (1982) Experiment in plant tissue culture. Cambridge University Press. London

Ganesan CM, Paulsamy S (2011) Standardized protocol for the in vitro culture of Artemisia annua L.: A medicinal plant at high altitudes of Nilgiris, 
Wahyuni $d k k$., Perkembangan Kultur .... 15

The Western Ghats. Journal of Research in Biology 3:173-178

George EF, Sherrington PD (1984) Plant propagation by tissue culture. Cambridge University Press. London

Hoesen DSH, Witjaksono, Sukamto LA (2008) Induksi kalus dan organogenesis kultur in vitro Dendrobium lineale Rolfe. Berita Biologi 9: 333-341

Hendaryono DPS, Wijayani A (1994) Teknik kultur jaringan : Pengenalan dan petunjuk perbanyakan tanaman secara vegetatif modern. Penerbit Kanisius. Yogyakarta

Ibrahim MSD, Rostiana O, Khumaidah N (2010) Pengaruh umur eksplan terhadap keberhasilan pembentukkan kalus embriogenik pada kultur meristem jahe (Zingibe officinale Rosc.). Jurnal Litri 16:37-42

Jahan MT, Islam MR, Khan $R$, Mamun ANK, Ahmed G, Hakim L (2009) In vitro clonal propagation of anthurium (Anthurium andraeanum L.) using callus culture. Plant Tissue Culture and Biotechnology 19: 61-69

Komal R (2011) Effect of BAP and IAA on callus formation and plant regeneration in pointed gourd. Research Article Biotechnology Bioinformation Bioengineering 1: 59-62

Laohavisuti N, Mitrnoi M (2005) Micropropagation of aglaonema simplex. $43^{\text {th }}$ Kasetsart University Annual Conference Proceedings. Thailand

Mariani ST, Fitriani A, Jaime A, da Silva T, Wicaksono A, Chia FT (2011) Micropropagation of Aglaonema using axillary shoot explants. International
Journal of Basic and Applied Sciences IJBAS-IJENS. 11(1)

Melara MV, Andres M, Arias G (2009) Effect of BAP and IAA on shoot regeneration in cotyledonary explant of Costa Rican melon genotypes. Agronomia Costarricense 33: 125-131

Murashige T, Skoog F (1962) A revised medium for rapid growth and bioassays with tobacco tissue culture. Physiologia Plantarum 15: 473

Rachmawati Y (2008) Induksi kalus dari eksplan daun dan tangkai daun wave of love (Anthurium plowmanii Croat.) dengan kombinasi zat pengatur tumbuh auksin dan sitokinin secara in vitro. Skripsi. Departemen Biologi. Fakultas Sains dan Teknologi. Universitas Airlangga. Surabaya

Rachmawati D, Hosaka T, Inoue E, and Anzai $\mathrm{H}$ (2004) Agrobacterium-mediated tranformation of Javanica rice cv. Rojolele. Bioscience Biotechnology Biochemistry 68:1193-1200

Rashid U, Ali S, Ali GM, Ayub N, Masood MS (2009) Establishment of an efficient callus induction and plant regeneration sistem in Pakistani wheat (Triticum aestivum L.) cultivars. Electronic Journal of Biotechnology 12: 1-12

Reddy JM, Bopaiah AK, Abhilash M (2011) In vitro micropropagation of Anthurium digitatum using leaf as explant. Asian Journal of Pharmaceutical and Health Sciences 3:70-74

Shirin F, Hossain M, Kabir MF, Roy M, Sarker SR (2007) Callus induction and plant 
16 JURNAL BIOSLOGOS, FEBRUARI 2014, VOL. 4 NOMOR 1

regeneration from internodal and leaf explant of for potato (Solanum tuberosum L.). Journal of Agricultural Science 3:1-6

Sukmadewi I, Wahyuni DK, Purnobasuki H (2012) Perkembangan kultur daun Aglaonema sp. var Siam Pearl, Aglaonema sp. var. Lady Valentin dan Aglaonema sp. var. Lipstik dengan perlakuan zat pengatur tumbuh IAA dan BAP. Berkala Penelitian Hayati 17:197-204

Qodriyah L, Sutisno A (2007) Teknik perbanyakan vegetatif beberapa aksesi Aglaonema menggunakan stek mata tunas tunggal dengan batang terbelah. Buletin Teknik Pertanian 12(2)

Sridhar TM, Naidu CV (2011) An efficient callus induction and plant regeneration of Solanum nigrum L.: An important antiulcer medicinal plant. Journal of Phytology 3: 23-28

Subono M, Andoko A (2004) Meningkatkan kualitas Aglaonema sang ratu pembawa rezeki. Agromedia Pustaka. Jakarta

Syahid SF, Kristina NN (2007) Induksi dan regenerasi kalus keladi tikus (Typonium flagelliforme Lodd.) secara in vitro. Jurnal Litri 13:142-146

Taiz L, Zeiger E (1998) Plant physiology. $2^{\text {nd }}$ Edition. Sinauer Associates Inc. Sunderland.

Tripathy S, Reddy GM (2002) In vitro callus induction and plantlet regeneration from Indian cotton cultivars. Plant Cell Biotechnology and Molecular Biology 3:137-142

Wahyuni DK, Utami ESW, Ekasari W, Wahyuni TS (2010) Callus induction of Sonchus arvensis L. and its in-vitro antiplasmodial activity. Proceeding of International Conference on Medicinal Plants. Pokjanas TOI-Widya Mandala Catholic University. Surabaya.

Wannakrairoj S (2000) Axenic clonal propagation of Aglaonema. Abstract. http://agris.fao.org/agrissearch/search/display.do

Yulianto, R (2006) Studi induksi tunas aksilar Aglaonema Dona Carmen secara in vitro menggunakan kombinasi IAA dan Kinetin. Skripsi. Jurusan Budidaya Pertanian Fakultas Pertanian Universitas Muhammadiyah Malang. Malang 